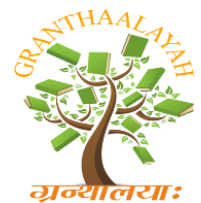

INTERNATIONAL JOURNAL OF RESEARCH GRANTHAALAYAH

A knowledge Repository

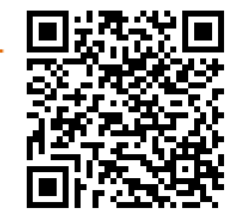

Management

\title{
ADOPTION OF RENEWABLE ENERGY TECHNOLOGIES (RET) IN TOURISM INDUSTRY - (A CASE OF OSOGBO AND OLORUNDA LOCAL GOVERNMENT AREAS IN OSUN STATE, NIGERIA)
}

\author{
Sonubi, O.K. ${ }^{* 1}$, Ogunjimi, A. A. ${ }^{2}$, Adeyemo, A. I. ${ }^{3}$ \\ ${ }^{* 1}$ Hospitality, Leisure and Tourism Management Dept, Federal Polytechnic, Ede, Osun State, \\ NIGERIA \\ ${ }^{2,3}$ Ecotourism and Wildlife Management Dept, Federal University of Technology, Akure, Ondo \\ State, NIGERIA
}

\begin{abstract}
Hotel accommodation in Nigeria is comparatively more expensive than its neighbours in the sub region of West Africa. It is one of the most expensive globally. This is attributable to its operating environment. Any sustainable means of reducing running costs would be most welcome. A study on adoption of renewable energy technologies (RET) was conducted in Osogbo and Olorunda Local Government Areas of Osun State, Nigeria. Data were obtained from registered hotels in the two local government areas through structured questionnaires. Results were presented descriptively. Knowledge and awareness about RET were high among the managers of the hotels with $82.5 \%$. Solar energy technology was the most popular among the respondents with $65.0 \%$, while radio and internet constituted the highest sources of knowledge and awareness with $30.0 \%$ and $22.5 \%$ respectively. Among the hotels, $30.0 \%$ have adopted RET with the level of adoption stated to be moderate and low with $41.7 \%$ respectively. Solar energy technology was the most RET adopted with $83.3 \%$ of respondents. Among the hotels that have not adopted RET, 92.9\% were willing to adopt RET, with all of them (100\%) willing to adopt solar energy. However, $7.1 \%$ of those currently not adopting RET had previously adopted solar energy technology. Cost of maintenance of the technology, lack of expertise in maintenance and lack of spare parts were ranked first, second and third respectively as reasons for discontinuance of adoption of the technology. For the hotels that have adopted RET, appreciable savings (15\%) on cost of running was made, encouraging the provision of gym and outdoor recreational facilities, thereby leading to physical wellness of their customers. There is need for major policy shift by government in favour of solar energy technology and adoption. This policy should not be on awareness alone, but also in the provision of solar energy backbones and infrastructures, training and capacity building in installation, equipment parts and maintenance of the technology in order to increase and sustain adoption in tourism sector.
\end{abstract}

Keywords:

Renewable energy; Hotels; Technology; Adoption and Customers. 
Cite This Article: Sonubi, O.K., Ogunjimi, A. A., and Adeyemo, A. I., "ADOPTION OF RENEWABLE ENERGY TECHNOLOGIES (RET) IN TOURISM INDUSTRY - (A CASE OF OSOGBO AND OLORUNDA LOCAL GOVERNMENT AREAS IN OSUN STATE, NIGERIA)" International Journal of Research - Granthaalayah, Vol. 3, No. 11(2015): 47-57.

\section{INTRODUCTION}

\section{OBJECTIVES OF THE STUDY}

The main objective of this study was to establish the fact that energy saving costs can appreciably reduce the hotel operating costs in Nigeria and thereby making the country more attractive to foreign tourists.

\section{REASONS FOR UNDERTAKING THE STUDY}

Nigeria, relative to its population size $(182,202,000 \mathrm{UN}, 2015)$ and abundant natural, cultural and man-made resources has the lowest (comparatively) tourists' arrival and income in sub-Saharan Africa. Africa has one of the lowest in the global tourism market. With the current estimates of Nigerian population reaching the $7^{\text {th }}$ (World Meters, 2015) most populated country in the world. There must be new ways of attracting appreciable tourists' dollars into Nigeria.

Africa has the lowest tourist arrivals in the world. In 2014, total global arrivals 1,133,000,000; Africa 55,000,000; Europe, 580,000,000; Asia and the Pacific 264,000,000 and Americas 181,600,000, UNWTO (2015). Within Africa, West Africa sub region has the lowest and Nigeria is the least visited with its population and geographical area comparatively. This study acknowledges that there are many other factors responsible for Nigeria's unattractiveness to international tourists but from the industry operational perspectives, there are some things that are impeding tourists' arrivals that can positively change things for better; reducing operational costs is one of the approaches and hence this study.

\section{INDUSTRY'S CURRENT SITUATION}

A recent research by the Hogg Robinson Group (HRG, 2012) has ranked hotels in Lagos as the second most expensive in the world behind Moscow. According to the results of a poll conducted in 50 cities worldwide, a hotel room in Lagos cost an average of $£ 217.05$. The report claimed the high rate of hotel rooms in the state could be attributed to the 'high volume of inbound business travel connected with the oil industry'. It added security concerns in the country; security forces travellers to stay in five-star accommodation. Patterson, has attributed the high cost of hotel rooms in Nigeria to market forces as the country is a popular destination. Patterson said the high prices charged by hotelier is market driven, "anywhere that is busy you find this type of issue, just like the airlines. Look at what the airlines charged to come to Lagos, it is expensive and again it is market forces.

Ajibola (2014) said despite the high number of hotels in Lagos, the metropolis remains the city with the highest charges on hotel accommodation in Africa. According to the Lagos State Hotel Licensing Authority, the agency responsible for regulating the hospitality industry, about 2,500 
hotels and other hospitality establishments are located in the state. Finding shows that all the fivestar hotels included in this survey, with branches in other African cities such as Johannesburg, South Africa, Nairobi, Kenya; Lusaka, Zambia, Maputo, Mozambique, Dar es Salam, Tanzania and Balaclava, Mauritius charge much higher room rates in Lagos than they do in other African cities. The price difference sometimes is as high as 148 per cent. For example, the standard room rate in Southern Sun Ikoyi, Lagos costs N62,000 per night, whereas the same room costs an equivalent of N25,000 in Southern Sun, Johannesburg, South Africa. A diplomatic suite with kingsize bed, which costs an equivalent of N149, 000 per night in Sheraton Hotel Pretoria, South Africa goes for N248,000 in Lagos Sheraton Lagos Hotel and Towers - a difference of 65 per cent.

The Director of Nigeria Tourism Development Corporation (NTDC), Mrs. Sally Mbanefo, whose organisation last year lost the regulatory power over hotels operation in Lagos and other states of the federation through a Supreme Court ruling, also stressed market forces as the major significant factor determining prices of hotel accommodation. According to her, price equilibrium is bound to go higher when the demand for hotel accommodation is higher than the supply. Plausible as this explanation may sound, it appears a weak justification for such huge difference in the hotel room rates in Lagos compared to other African cities.

However, the more powerful argument by hotel operators in Lagos and other Nigerian cities is that, high operational cost is the primary cause of the exorbitant prices of hotel rooms. At the second Nigeria Tourism Investors Forum and Exhibition (NTIFE) held in Abuja recently by Federation of Tourism Association of Nigeria (FTAN), stakeholders at the summit submitted that the cost incurred in running hotels in Nigeria is "outrageously high." In his paper, FTAN President, Mr. Tomi Akingbogun highlighted lack of key infrastructure in the country among other factors hindering the growth of hotel business in Nigeria.

Because of inadequate supply of basic amenities such as electricity and water, most hotel operators now procure their own transformers and generator sets, dig their own boreholes and install water treatment plants, said Akingbogun who himself owns a hotel in Abuja. He said hotel owners also invest huge capital in security that government has failed to guarantee in the country. All these costs are incidental on the high markup in hotel charges.

The former Lagos State Commissioner for Tourism and Intergovernmental Relations, Mr. Disun Holloway, said the sole cost of running generators to produce power, which many other countries take for granted, impacts heavily on overheads of operating hotels in Lagos. While Nigeria can only supply 4,000 megawatts of electricity in 2014, South Africa electricity capacity is about 45,700 MW, according to South Africa's Department of Energy (DOE). Krishna said his organisation, Intercontinental Hotel for instance, generates 50 per cent of its power supply through diesel-power generating set.

There is also the problem of multiple taxes, charges, which eat deep into the revenue of investors in tourism industry, and drive away potential investors. These include bills such as business premises registration fees, signboard fees, tenement rate, liquor licence, Nigeria Social Insurance Trust Fund (NSITF), value added tax, guest parking bill and water and electricity bills. Other costs, which make the room rates higher in Lagos than in other African cities, are employee costs and benefits, which Krishna said were the highest in Africa. This, however, contradicts a recent study 
by the World Bank which says the labour cost in Nigeria is actually lower than most of the country's competitors such as Brazil and South Africa.

\section{LITERATURE REVIEW}

Yglesias, (2012) stated that another reason for the high cost of hotels is their location. Mainstream hotels offer premium locations in central business districts or near key attractions, and they tend to invest in what you'd ordinarily consider an unreasonably high level of service. Hotel customers tolerate these marked-up amenities because they generally aren't very interested in driving a hard bargain. Tourists may be more frugal. But even so, for many vacationers (especially in America) time is in shorter supply than money, so it makes sense to invest extra money in ensuring that the time is well spent.

Energy is the second largest spending category for a hotel after employment, representing $3 \%$ to $6 \%$ of hotel operating costs and accounting for approximately $60 \%$ of its $\mathrm{CO}_{2}$ emissions, according to Energy Solutions, 2015. Lighting control, optimising room and water temperatures, and raising energy awareness among staff are just some of the options. Equally importantly, energy efficiency measures are not only going to prove economically beneficial but are also likely to benefit the reputation of your hotel, Holly (2013). Energy is an excellent focal point for reducing your expenses in a big way while still having your guests love you. Indeed, tourism is a key talking point in debates on sustainability. The sector's carbon impact is $2 \%$ of the earth's total but will soon increase to $3 \%$ due to the fast growing tourist demand (from 25 million travelers in 1950 to 1 billion in 2012, and forecasted to reach 1.8 billion in 2030, according to the United Nations World Tourism Organization, which has urged the tourism industry to take sustainability measures), Vadam (2015).

Patterson (2013), has attributed the high cost of hotel rooms in Nigeria to market forces as the country is a popular destination. Demand is continuing to pick up with the supply; it is similar to the airlines. All the airlines coming into the country fly in full, so it is good and the hotels in Nigeria are predominantly expensive. Lagos is the second most expensive city in the world, perhaps Moscow for hotels. Despite the high number of hotels in Lagos, the metropolis remains the city with the highest charges on hotel accommodation in Africa, Ajibola (2014). Akingbogun (2013) said because of inadequate supply of basic amenities such as electricity and water, most hotel operators now procure their own transformers and generator sets, dig their own boreholes and install water treatment plants. Hotel owners also invest huge capital in security that government has failed to guarantee in the country. All these costs are incidental on the high markup in hotel charges. Holloway (2013), said the sole cost of running generators to produce power, which many other countries take for granted, impacts heavily on overheads of operating hotels in Lagos.

Energy is an excellent focal point for reducing your expenses in a big way while still having your guests love you, Bair (2012). Energy is the second largest spending category for a hotel after employment, emissions, according to Bair, Energy expenses representing 3\% to 6\% of hotel operating costs and accounting for approximately $60 \%$ of its $\mathrm{CO}_{2}$. 


\section{MATERIALS AND METHODS}

\section{THE STUDY AREA}

Osogbo is a world heritage site hosting city. Osogbo the capital of Osun State lies on coordinates $7^{\circ} 46^{\prime}$ North $4^{\circ} 34^{\prime}$ East with an area of $47 \mathrm{kmsq}$. According to the 2006 Population and Housing Commission Census, the city has a population of 156,694 people. Osogbo shares boundary with Ikirun, Ilesa, Ede, Egbedore and Iragbiji and is easily accessible from any part of the state because of its central nature. It is about $48 \mathrm{~km}$ from Ife, $32 \mathrm{~km}$ from Ilesa, $46 \mathrm{~km}$ from Iwo, $48 \mathrm{~km}$ from Ikire and 46km from Ila-Orangun, (Osun gov, 2015).

Osogbo is a commercial and industrial centre. This started in 1907, when the British Cotton Growing Association sited an industry for growing and ginning of cotton. The Nigerian Tobacco Company (NTC) built its first factory in Osogbo. In this same year, a major turning point for the city which helped in its industrial and commercial development occurred. The railway tracks were constructed linking it to other parts of Nigeria. This attracted people from far and near (Osun gov., 2015).

The Ataoja of Osogbo is the traditional title of the King and he is the political and spiritual heads of Obas and Chiefs in Osogbo and Olorunda Local Government Areas. Osogbo is famous for the annual Osun Osogbo Festival which attracts tourists from different part of the world, (Osun gov., 2015).

\section{POPULATION AND SAMPLING PROCEDURES}

This study focused on the registered hotels in the capital city of Osogbo with its two local government areas: Olorunda and Osogbo local government areas. Samples of registered hotels were drawn from the target population using Krejcie and Morgan (1970) method of determining sample size. To obtain the sample for this study, a random sample of hotels categories in five classifications were sampled.

\section{DESIGN AND INSTRUMENT FOR DATA COLLECTION}

The study was designed to get the hotel practitioners involved in the study. Objective of the study was carefully explained and demonstrated. Staff and management of the randomly chosen willingly participated in the study. Structured questionnaire was used to collect data for the survey. The questionnaire survey was divided into different sections to collect data on the characteristics of the hotel and the owners; knowledge and awareness about renewable energy technology; awareness media; adoption of renewable energy technology; and reasons for adopting or not adopting, and challenges faced in the process of adoption. Age, sex, marital status, tribe or race or nationalities were not factors considered in the selection process. All were randomly chosen.

\section{RESULTS}

\section{CHARACTERISTIC OF OWNER/HOTELS}


Table 1 presents the characteristics of the owner/hotels. It shows that $42.5 \%$ of them were 5 star hotel, $50.0 \%$ had been in operation for more than 15 years, $90 \%$ of owners were male, $27.5 \%$ and $20.0 \%$ had workforce of between 6-10 and 11-15 respectively. In addition, $60.0 \%$ of the hotels had monthly turnover between $¥ 0$ - $20,000,75.0 \%$ experience average patronage and $62.5 \%$ had monthly number of guests between the ranges of 0-50.

Table 1: Characteristics of Hotel / Owner

\begin{tabular}{|c|c|c|}
\hline VARIABLES & FREQUENCY & PERCENTAGES \\
\hline \multicolumn{3}{|l|}{ Hotel Category (Star) } \\
\hline 1 & 3 & 7.5 \\
\hline 2 & 1 & 2.5 \\
\hline 3 & 8 & 20.0 \\
\hline 4 & 11 & 27.5 \\
\hline 5 & 17 & 42.5 \\
\hline \multicolumn{3}{|l|}{ Operational Year } \\
\hline $0-5$ & 8 & 20.0 \\
\hline $6-10$ & 6 & 15.0 \\
\hline $11-15$ & 6 & 15.0 \\
\hline$>15$ & 20 & 50.0 \\
\hline \multicolumn{3}{|c|}{ Education of the Owner } \\
\hline \multicolumn{3}{|l|}{ Gender of the Owner } \\
\hline Female & 4 & 10 \\
\hline Male & 36 & 90 \\
\hline \multicolumn{3}{|l|}{ Number of Workforce } \\
\hline $0-5$ & 7 & 17.5 \\
\hline $6-10$ & 11 & 27.5 \\
\hline $11-15$ & 8 & 20.0 \\
\hline $16-20$ & 7 & 17.5 \\
\hline$>20$ & 8 & 17.5 \\
\hline \multicolumn{3}{|l|}{ Employee Status } \\
\hline Permanent staff & 40 & 100 \\
\hline Part time staff & 40 & 100 \\
\hline \multicolumn{3}{|l|}{ Monthly Turnover } \\
\hline $0-20,000.00$ & 24 & 60.0 \\
\hline $21,000.00-40,000.00$ & 3 & 7.5 \\
\hline $41,000.00-60,000.00$ & 1 & 2.5 \\
\hline$>60,000.00$ & 12 & 30.0 \\
\hline \multicolumn{3}{|l|}{ Patronage } \\
\hline High & 5 & 12.5 \\
\hline Average & 30 & 75.0 \\
\hline Low & 5 & 12.5 \\
\hline \multicolumn{3}{|c|}{ Monthly Number of Guests } \\
\hline $0-50$ & 25 & 62.5 \\
\hline $51-100$ & 5 & 12.5 \\
\hline $101-150$ & 2 & 5.0 \\
\hline
\end{tabular}




\begin{tabular}{|l|l|l|}
\hline $151-200$ & 3 & 7.5 \\
\hline$>200$ & 10 & 25.0 \\
\hline
\end{tabular}

\section{KNOWLEDGE AND AWARENESS ABOUT RENEWABLE ENERGY TECHNOLOGY}

Table 2 revealed that $87.5 \%, 35.0 \%, 97.5 \%, 97.5 \%, 92.5 \%, 0 \%, 95.0 \%$ and $75.0 \%$ of the owner/hotel had the knowledge and are aware of wind energy, solar energy, tidal energy, wave energy, biomass energy, geothermal energy, ethanol and hydroelectricity respectively.

\section{AWARENESS MEDIA}

Table 3 showed that $30 \%$ of the respondents indicated Radio as their renewable energy knowledge and awareness media, $22.5 \%$ and $20.0 \%$ indicated internet and newspaper as theirs respectively.

\section{ADOPTION OF RENEWABLE ENERGY TECHNOLOGY}

Table 4 presents the information on adoption of renewable energy technologies. It shows that $70 \%$ of them had adopted the technologies, with adoption level at $12.5 \%$. Solar energy (15.0\%) is most adopted energy technology.

\section{REASONS FOR ADOPTION}

Table 5 presents the reasons for adoption of new technologies. The result shows that $20.0 \%$ and $12.5 \%$ of the respondents indicated renewable energy enhances sustainability of the energy systems and the environment as most important and averagely important respectively. Also $17.5 \%$ chose as most important, that using renewable energy technologies are safe. In addition 15\% of them indicated renewable energy technologies are economically balanced and has long service life as most important.

Table 2: Knowledge and Awareness about Renewable Energy Technology

\begin{tabular}{|l|l|l|}
\hline VARIABLES & YES & NO \\
\hline Knowledge and Awareness & & \\
\hline Wind Energy & 87.5 & 12.5 \\
\hline Solar Energy & 35.0 & 65.0 \\
\hline Tidal Energy & 97.5 & 2.5 \\
\hline Wave Energy & 97.5 & 2.5 \\
\hline Biomass Energy & 92.5 & 7.5 \\
\hline Geothermal & 0 & 0 \\
\hline Ethanol & 95.0 & 5.0 \\
\hline Hydroelectricity & 75.0 & 10.0 \\
\hline
\end{tabular}

Table 3: Renewable Energy Knowledge and Awareness Media.

\begin{tabular}{|l|l|l|}
\hline VARIABLES & FREQUENCY & PERCENTAGES \\
\hline Newspapers & 8 & 20.0 \\
\hline Radio & 12 & 30.0 \\
\hline Government Agencies & 3 & 7.5 \\
\hline
\end{tabular}




\begin{tabular}{|l|l|l|}
\hline Television & 8 & 20.0 \\
\hline Friends and Families & 3 & 7.5 \\
\hline Other Hotels & 0 & 0.00 \\
\hline Internet & 9 & 22.5 \\
\hline Professional Associations & 4 & 10.0 \\
\hline
\end{tabular}

Table 4: Adoption of Renewable Energy Technologies

\begin{tabular}{|l|l|l|}
\hline VARIABLES & FREQUENCY & PERCENTAGES \\
\hline Adoption & & \\
\hline Yes & 12 & 30 \\
\hline No & 28 & 70 \\
\hline Level of Adoption & & \\
\hline High & 2 & 5.0 \\
\hline Moderate & 4 & 10.0 \\
\hline Low & 5 & 12.5 \\
\hline Adopted Technologies & & \\
\hline Wind & 0 & \\
\hline Solar & 6 & 15.0 \\
\hline Tidal & 0 & \\
\hline Wave/Marine Currents & 1 & 2.5 \\
\hline Biomass & 1 & 2.5 \\
\hline Geothermal Heat & 0 & \\
\hline Ethanol Fuel & 0 & \\
\hline Hydroelectricity & 4 & 10.0 \\
\hline
\end{tabular}

Table 5: Reasons for Adoption

\begin{tabular}{|l|l|l|l|}
\hline REASONS FOR ADOPTION & $\begin{array}{l}\text { MOST } \\
\text { IMPORTANT }\end{array}$ & $\begin{array}{l}\text { AVERAGE } \\
\text { IMPORTANT }\end{array}$ & $\begin{array}{l}\text { LEAST } \\
\text { IMPORTANT }\end{array}$ \\
\hline Perceived Usefulness & & $5(12.5)$ & $32(80.0)$ \\
\hline $\begin{array}{l}\text { Using Renewable Energy Technologies } \\
\text { economically causes me to be more } \\
\text { convenient }\end{array}$ & $3(7.5)$ & $31(77.5)$ \\
\hline $\begin{array}{l}\text { Using Renewable Energy Technologies is } \\
\text { safe }\end{array}$ & $3(17.5)$ & $2(5.0)$ & $31(77.5)$ \\
\hline $\begin{array}{l}\text { Renewable Energy Technologies is clean and } \\
\text { for health }\end{array}$ & $6(15.0)$ & $3(7.5)$ & $30(75.0)$ \\
\hline $\begin{array}{l}\text { Renewable Energy Technologies service life } \\
\text { is long }\end{array}$ & $6(15.0)$ & $4(10.0)$ & $30(75.0)$ \\
\hline $\begin{array}{l}\text { The whole says, the usability of Renewable } \\
\text { Energy Technologies is very high }\end{array}$ & $5(12.5)$ & $5(12.5)$ & $32(80.0)$ \\
\hline Perceived ease of use & & $2(5.0)$ & $32(80.0)$ \\
\hline $\begin{array}{l}\text { Learning on how to use Renewable Energy } \\
\text { Technologies is easy }\end{array}$ & $6(15.0)$ & $3(7.5)$ & \\
\hline $\begin{array}{l}\text { Maintenance of Renewable Energy } \\
\text { Technologies is easy }\end{array}$ & $5(12.5)$ & & \\
\hline
\end{tabular}




\begin{tabular}{|l|l|l|l|}
\hline $\begin{array}{l}\text { It is easy to use Renewable Energy } \\
\text { Technologies without mistakes }\end{array}$ & $5(12.5)$ & $3(7.5)$ & $32(80.0)$ \\
\hline $\begin{array}{l}\text { In general it is easy to use Renewable Energy } \\
\text { Technologies }\end{array}$ & $5(12.5)$ & $3(7.5)$ & $32(80.0)$ \\
\hline Environmental Considerations & & $1(2.5)$ & $33(82.5)$ \\
\hline $\begin{array}{l}\text { The supply of energy needs from natural } \\
\text { resources is more suitable for environmental } \\
\text { considerations }\end{array}$ & $6(15.0)$ & $4(10.0)$ & $31(77.5)$ \\
\hline $\begin{array}{l}\text { The greenhouse gasses that come out because } \\
\text { of fossil fuels cause some of the heat to stay } \\
\text { within the atmosphere cause global warming. }\end{array}$ & $5(12.5)$ & $3(7.5)$ & $31(77.5)$ \\
\hline $\begin{array}{l}\text { Renewable Energy is important for the } \\
\text { ecologic balance }\end{array}$ & $6(15.0)$ & $5(12.5)$ & $31(77.5)$ \\
\hline $\begin{array}{l}\text { Using Renewable Energy resources would } \\
\text { remove the negative effects of the greenhouse } \\
\text { gasses }\end{array}$ & $4(10.0)$ & $2(5.0)$ & $30(75.0)$ \\
\hline $\begin{array}{l}\text { Renewable Energy enhances sustainability of } \\
\text { the energy systems and the environment. }\end{array}$ & $8(20.0)$ & & \\
\hline
\end{tabular}

\section{CHALLENGES FACED IN ADOPTION OF RENEWABLE ENERGY TECHNOLOGIES}

Table 6 reveals challenges faced in adoption of renewable energy technologies. It shows that $12.5 \%$ chose negative effect of weather on the equipment as most challenges faced.

\section{NON-ADOPTION OF RENEWABLE ENERGY TECHNOLOGIES}

Table 7 represents reasons non-adoption of renewable energy technologies. It shows that cost of acquisition (47.5\%) is the most reason for non-adoption of renewable energy technologies. The least reason is maintenance $(50.0 \%)$. Table 8 shows the willingness to adopt RET. It shows that $67.5 \%$ were willing $27.5 \%$ were not willing.

\section{REASONS FOR DISCONTINUING ADOPTION}

Table 10 shows that $7.5 \%$ and $90.0 \%$ of the respondents indicated the cost of maintenance as most reason and least reason respectively. $95.0 \%$ chose constant breakdown of equipment as least reason for discontinuing adoption.

Table 6: Challenges Faced in Adoption of Renewable Energy Technologies

\begin{tabular}{|l|l|l|l|}
\hline CHALLENGE & $\begin{array}{l}\text { MOST } \\
\text { CHALLENGE }\end{array}$ & $\begin{array}{l}\text { MODERATE } \\
\text { CHALLENGE }\end{array}$ & $\begin{array}{l}\text { LEAST } \\
\text { CHALLENGE }\end{array}$ \\
\hline Cost of Maintenance & $5(12.5)$ & $2(5.0)$ & $33(82.5)$ \\
\hline Inadequate Experts for Maintenance & $2(5.0)$ & $3(7.5)$ & $35(87.5)$ \\
\hline Regular Breakdown of Equipment & $2(5.0)$ & $4(10.0)$ & $34(85.0)$ \\
\hline $\begin{array}{l}\text { Negative Effect of weather on the } \\
\text { Equipment }\end{array}$ & $5(12.5)$ & $2(5.0)$ & $33(82.5)$ \\
\hline Stolen Equipment & $1(2.5)$ & $8(20.0)$ & $31(77.5)$ \\
\hline
\end{tabular}


Table 7: Non-Adoption of Renewable Energy Technologies

\begin{tabular}{|l|l|l|l|}
\hline REASONS & MOST & MODERATE & LEAST \\
\hline Cost of Acquisition & $19(47.5)$ & $5(12.5)$ & $16(40.0)$ \\
\hline Maintenance & $13(32.5)$ & $7(17.5)$ & $20(50.0)$ \\
\hline Lack of Information & $11(27.5)$ & $6(15.0)$ & $23(57.5)$ \\
\hline Unavailability & $7(17.5)$ & $8(20.0)$ & $25(62.5)$ \\
\hline
\end{tabular}

Table 8: Willingness to Adopt R E T

\begin{tabular}{|l|l|l|}
\hline VARIABLES & FREQUENCY & PERCENTAGES \\
\hline Willing & & \\
\hline Yes & 29 & 67.5 \\
\hline No & 11 & 27.5 \\
\hline $\begin{array}{l}\text { TechnologiesWilling to Adopt } \\
\text { Wind }\end{array}$ & & 7.5 \\
\hline
\end{tabular}

Table 9: What are the Reasons for Discontinuing Adoption?

\begin{tabular}{|l|l|l|l|}
\hline REASONS & MOST & MODERATE & LEAST \\
\hline Cost of Maintenance & $3(7.5)$ & $1(2.5)$ & $36(90.0)$ \\
\hline Lack of Expert for Maintenance & $2(5.0)$ & & $38(95.0)$ \\
\hline Constant Breakdown of Equipment & $1(2.5)$ & $1(2.5)$ & $38(95.0)$ \\
\hline
\end{tabular}

\section{DISCUSSION}

The categories of the hotels shows that $42.5 \%$ were of high level 5 star rating and more than $50 \%$ of all the hotels that participated in the study had been in operation for more than 15 years. Nearly all of them $(90 \%)$ are owned by the male gender. $47.5 \%$ of the hotels had workforce less than 20 , and $75 \%$ of them have not more than 100 guests monthly. This is an indication of the rural nature of the hotels location and the level of patronage, although there is a major tourist attraction in this community-Osun Osogbo Living Groove which is a World Heritage Site, indicating that most the visitors to this site are Day trippers. Most of the hotel owners/managers have good knowledge and awareness (table 2) about renewable energy technology and their source of information is mainly through the radio and to a lesser degree the internet and newspapers.

A good percentage (70\%) had adopted the technologies (table 4) but at a dismal level of $12.5 \%$ with solar energy leading. Their reasons for adoption is mainly based on renewable energy enhance sustainability of the energy systems and the environment. Considering the reasons for adoption (table 5), most reasons for adoption (highest most important) at 20\% are: renewable energy enhances sustainability of the energy systems and the environment followed by (17.5\%) using renewable energy technology is safe and (15\%) renewable energy is clean and for health; renewable energy technology service life is long; learning on how to use renewable energy technology is easy; the supply of energy needs from natural resources is more suitable for environmental considerations; and renewable energy is important for the ecological balance.

\section{CONCLUSION}

From this study, it is safe to conclude that the adoption of renewable energy technology in the study area is low owing to poor education or access to information, cost of maintenance and 
negative effects of the weather on the equipment as major challenges and cost of acquisition as the most important reasons for not adopting the technology.

\section{RECOMMENDATION}

Information from this study is convincing enough to make the following recommendations;

1) Hotel owners/managers should have more education/information on the advantages of adopting RET.

2) There is the need to subsidize the costs of RET for more hotels to adopt the technologies since costs is one of the main reasons for not adopting RET in the global interest.

3) Technologies that suit our local weather should be promoted and encouraged to reduce the effect of weather on maintenance costs.

\section{REFERENCES}

[1] Ajibola, A. (2014): The Guardian Newspapers, Nigerian Daily Publication. http://www.theguardianmobile.com/readNewsitem1.php?nid=32109

[2] Bair, A. (2012): 11 Tips for Quickly Reducing Energy Costs in Hotels. ehotelier.com/? $=11+$ tips + Quickly + Reducing + Energy + Costs + in + Hotels $\% 2 C+$ Bair +20 12

[3] Holloway, D.(2013): Ex Lagos State Commissioner for Tourism and intergovernmental Relations

[4] Holly T. (2013): Simple Steps to Reducing Energy Consumption. www.greenhoteliers.org/our- themes/energy/simple-steps-to-reducing-energy consumption/

[5] HRG: Hogg Robbinson Group (2012). http://news2.onlinenigeria.com/headline/189889lagos- hotels- are-the-second-most-expensive-in-the-world.html\#ixzz3afHJjvat

[6] Iarossi, G. (2011): World Bank; Benchmarking Africa's Costs and Competitiveness. Siteresources.worldbank.org/EXTAFRSUMAFTPS/

[7] Patterson, J. (2013): High Costs of Hotel Rooms in Nigeria. Vanguard Newspapers, 2013. :http://www.vanguardngr.com/2013/12/hotels-expensive-nigeriapatterson/\#sthash.3k8Z1iNo.dpuf

[8] UN, (2015): United Nations, Department of Economic and Social Affairs, Population Division (2015). $\quad$ World Population Prospects. The 2015 Revision. DVD Edition.

[9] UNWTO, 2015: UNWTO World Barometer and Statistical Annex, October 2015. www.eunwto.org/doi/pdf/10.18111/wtobarometereng.2015,13.5.1

[10] Vadam, C. (2015). How to Reduce Energy Consumption in Hotels. Hotels News Now. http://www.hotelnewsnow.com/Article/15701/How-to-reduce-energy-consumption-inhotels\#sthash.u9002q8m.dpuf

[11] World Meters. Top 20 Largest Countries by Population. www.worldmeters.info/worldpopulation/ www.un.org/en/development/desa/population/pdf/environment/populationConsumptionE nviro nment2015.pdf

[12] Yglesias, M. (2012): Hotels Costs: Why urban Hotels Cost so Much More than Houses. www.slate.com/articles/business/reader_takeover/2012/11/hotel_prices_why_urban_cost _so__much_more_than_houses 